Tropical Agricultural Research \& Extension 19 (2): 2016

\title{
TEA SMALL HOLDERS' PERCEPTIONS AND EXPERIENCE WITH TEA SMALL HOLDINGS DEVELOPMENT SOCIETIES (TSHDS) IN MATARA DISTRICT OF SRI LANKA
}

\author{
GG Bandula $^{1^{*}, \text { LM Abeywickrama }^{2} \text {, Mangala De Zoysa }}{ }^{2}$ \\ ${ }^{1}$ Tea Small Holdings Development Authority, Regional Office, Kalidasa Road, Matara, Sri Lanka \\ ${ }^{2}$ Faculty of Agriculture, University of Ruhuna, Mapalana, Kamburupitiya, Sri Lanka
}

\begin{abstract}
Tea Small Holdings Development Societies (TSHDS) have been established under the guidance of Tea Small Holdings Development Authority (TSHDA) in Sri Lanka. These Societies were expected to act as bridges among the tea small holders and other relevant organizations including TSHDA and to provide necessary services to the tea small holders in effective and efficient way and to identify the tea small holders actual needs and opportunities through feedbacks. However, with all the reforms in the tea small holdings sector and the institutional intervention, it is not clear that the objectives of the TSHDS have been achieved. Matara district is purposively selected for the study as it contributes more than $13 \%$ of the total tea production in the country and about $17 \%$ of the total tea small holders are residing in Matara. We used a structured questionnaire to interview randomly selected sixhundred tea small-holders selected from six DS. Thi is in addition, to focus group discussions, direct observations and discussions with relevant stakeholders. Descriptive Statistical Tools, Chi-square test, 't' test and Wilcoxon Sign Rank Test were used to analyze and to present data. The study revealed that the TSHDS has not addressed the needs of the tea small-holders in addition to the conventional activities such as advisory services and the government subsidies of TSHDA and other government authorities. Out of the total number of small holders in the sample only $15 \%$ were highly satisfied about the TSHDS and another $12 \%$ were partially satisfied. The results proved that there is no significant improvement of the tea small holdings sector due to implementation of Tea Societies. The study suggests to strengthen TSHDS through continuous training and providing other necessary assistances to enable them to improve advisory and extension services. In addition, distribution of tea cultivation subsidy more efficiently and effectively to their members with the assistance of the TSHDA to improve the productivity of the tea small holdings. The study also recommends reviewing the structure and function of the TSHDS in order to revitalize the Societies which may be crucial to face the problems of low productivity, degradation of the quality and other emerging issues in the future.
\end{abstract}

Key words: Tea Small Holders, Tea Small Holdings, Tea Small holdings Development Societies

\section{INTRODUCTION}

Sri Lanka is one of the oldest tea producing countries in the World; it commenced commercial scale tea production in 1867 . Tea sector is the one of the vital sectors in the economy of Sri Lanka. It consists of two main sectors: the corporate sector and the tea small holdings.

Tea small holdings sector plays major role in

*Corresponding author: ggbandula@gmail.com the tea sector in Sri Lanka while contributing over $73 \%$ to the total tea production, operating about 370,842 tea small holders with 397,223 tea holdings with nearly $60 \%$ of the total tea extent in the island (Census of Tea Small Holdings in Sri Lanka 2005).

Tea cultivation has begun as large plantations but with the gradual changes of the economy, tea planting in small land blocks has become 
increasingly popular leading to the development of small holder sector in the country. Land redistribution programs implemented by the government after land reform has also caused to increase the number of tea small holders in the country. At present, large plantations and small private estates mainly exist in up and mid country area while small holders are dominant in low country $(0-300 \mathrm{~m}$ MSL) (Palihakkara et al 2015a).

About 46,241 tea holdings found to be less than 20 perches, which are considered as the smallest. About $86 \%$ of the small holdings are less than 0.5 ha and the extent covered by this group is about $51.4 \%$ of the total extent under the small holding sector. All these operated as family enterprises. Therefore small scale tea small holders are very important in this sub sector (Census of Tea Small Holdings in Sri Lanka, 2005; Palihakkara et al 2015b).

With the expansion of the tea small holdings sector, the Tea Small Holdings Development Societies (TSHDS) were established in 1989 and registered under the Act No. 36 of 1991 to provide the services to the tea small holdings sector and to improve the well pare facilities of the tea small holders. These tea societies get legal status under the Act No. 21 of 1996 (Tea Small Holdings Development Authority 2014).

At present, there are 1,366 TSHDS at village level covering all the tea growing areas in the island and more than $50 \%$ of the tea small holders have got the membership of those societies (Tea Sakthi Fund 2016).

In addition to village level TSHDS at the regional level, there are eight regional tea development societies covering all the regions of the TSHDA and all island tea society federation has formed nominating officers from eight regional tea development societies at the national level. These tea society officers have the rare opportunity to nominate their members to the Board of Directors of all the government tea sector organizations in Sri Lanka. Therefore even the village level tea small holder has the path to express his views and forward his problems to the higher authorities.

By providing these opportunities to the TSHDS, the tea sector organizations, especially the TSHDA expected these TSHDS to act as the bridge between the tea small holders and the relevant organizations in the tea sector in Sri Lanka. These organizations expected to provide the necessary services to the tea small holders in effective and efficient way and to get the TSHs actual needs and opportunities through their feedback.

However, with all the reforms in the tea small holdings sector and the institutional intervention, it is not clear the objectives of the establishment of Tea Societies were achieved. This study aims to find the views of the society members and non-members about tea small holdings development societies and to make suggestions and recommendations to improve the status of the tea societies to enable them to do better service for their members with the specific objectives of (1) to find the factors influencing the active membership of the tea societies (2) to find the tea small holders' views of the societies and the activities (3) to find the benefits and achievements of the tea small holdings sector with the operations of tea societies and (4) to give suggestions and recommendations to develop the tea small holding sector through the present institutional setup.

\section{METHODOLOGY}

Matara district is purposively selected for the study as it produces about 43 million $\mathrm{kg}$ of made tea annually and contributes more than $13 \%$ of the total tea production of the island. The district itself have more than $17 \%$ of the total tea small holdings and about $17 \%$ of the tea small holders and it has about $19 \%$ of the total tea extent in the tea small holdings sector in Sri Lanka.

There are 186 TSHDS and reported to have the 
society membership about $50 \%$ of the 63,273 total tea small holders in the Matara district.

Out of the 13 Divisional Secretariat (DS) in the district, Pitabeddara, Kotapola, Akuressa, Athuraliya, Mulatiyana and Pasgoda are main tea growing DS which contribute more than $90 \%$ of the total production and the extent. About $93 \%$ of the tea small-holders $(58,943)$ are living in those DS divisions.

Six hundred tea small holders were randomly and proportionately selected as a sample group from Pitabeddara, Kotapola, Akuressa, Athuraliya, Mulatiyana and Pasgoda DS divisions covering 16 Tea Inspector/Extension Officer (TI/EO) ranges of the TSHDA.

Personal interviews were conducted at the tea small holders' fields or homes using the structured questionnaire schedule for primary data. In addition to the sample survey, direct observations at the fields, and focus group discussions to verify some of the information were conducted. Secondary information was collected from the compiled sources of TSHDA and its publications.

Descriptive statistical tools were used to present the data while Chi-square test was used to find the associations between demographic variables and the interest of society membership. The ' $t$ ' statistics was used to test the differences of selected attributes between members and non-members of the tea small holding societies. The Wilcoxon Sign Rank Test was employed to find the changes of different aspects of the tea small holding sector due to the activities.

\section{RESULTS AND DISCUSSION}

The study revealed that only about $50 \%$ of the small holders are having the active membership of tea development societies and, although, there are $70 \%$ of the small holders are well aware about the tea development societies. Majority of the non-members (72\%) are still not interested to have the membership while some of them (14\%) stated that having the membership is not useful for their activities.

However, $75 \%$ of the society members and $85 \%$ non members believed that the TSHDS can do better service for their members if the society constitution will be changed according to the actual views and ideas of their members.

Average yield of the tea small holders in the sample was $795 \mathrm{~kg} / \mathrm{ha}$ of green leaf per month ranging between $370-1,729 \mathrm{~kg} /$ ha showing a considerable variation. The average yield of the members of the TSHDS was higher (978 $\mathrm{kg} / \mathrm{ha}$ ) than the average of non-members of TSHDS although the difference is not significant due to large variation. It implies that the TSHDS has an impact on improving the productivity of tea small holding sector although the improvement is not statistically proved.

The Chi/Square analysis proved that there are no significant associations between the active membership of TSHDS and the demographic factors; age, education level or the gender of the small holder. Also no statistically significant association found between the active membership and the holding size although seemingly it shows that smaller size holders are having more tendency to be active members.

The main objectives of the members to be linked with the TSHDS were questioned in the survey and table1 summarize different reasons for involving with the activities of TSHDS.

We observed that only $8 \%$ of the members sell their green leaves through tea societies (Table 1). It is understood that due to well developed marketing channel implemented by private tea factories and green leaf collectors, many of the tea small holders sell their green leaves to the tea factories. 
About $88 \%$ of the tea society members developed their contacts with societies to get the advisory services through societies from the extension officers of the TSHDA and other organizations and $63 \%$ of the members like to continue the membership to get the tea subsidy to cultivate their tea small holdings and to get other benefits given by the government in time to time.

The survey also revealed that only $17 \%$ of the members obtain fertilizer through tea societies while only $6 \%$ of their members get easy loans with the assistance of tea societies and $13 \%$ of the society members get necessary inputs such as agro chemicals through tea societies.

The TSHDS only provide social welfare facilities to $13 \%$ of their members and sharing equipment such as sprayers, land preparation tools, plucking machines, pruning machines for only $20 \%$ of their members. The TSHDS should develop their capacities to provide more welfare facilities to their members and to provide required machineries to overcome the labor shortage faced by the tea small holders.

Therefore it is clear that yet to address the requirements of the tea small holders in addition to the conventional activities such as advisory services and the government subsidies of TSHDA and other government authorities. Out of the total number of small holders in the sample only $15 \%$ are highly satisfied about the TSHDS and another $12 \%$ are partially satisfied. However, there were $27 \%$ of the small holders who are not satisfied about the activities of the TSHDS. The results of the analysis through the Wilcoxon Sign Rank Test prove that there is no significant improvement of the tea small holding sector due to implementation of TSHDS.

Out of the non-members of TSHDS, 22\% showed interest to obtain membership of the societies while $26 \%$ were did not show any interest. Insufficient time is the barrier for about $50 \%$ of the non-members to participate actively in the activities of TSHDS and about $30 \%$ believed the assistance of TSHDS is not important for improvement of the productivity and other aspects of their tea plantations.

However these TSHDS can play main role in disseminating advices and information to tea small holders and giving feedback about the actual needs and requirements of the tea small holders to the TSHDA and other related organizations. These TSHDS can be facilitated to network with other groups, forming strong

Table 1. Reasons for continuing as an active member of TSHDS

\begin{tabular}{lc}
\hline Reason & $\begin{array}{c}\text { Percentage of small holders } \\
\text { reported }\end{array}$ \\
\hline $\begin{array}{l}\text { Guarantee to sell the green leaves } \\
\text { Guarantee to obtain fertilizer in time and reliability }\end{array}$ & $8 \%$ \\
$\begin{array}{l}\text { For advisory services } \\
\text { For tea cultivation subsidy and other benefits } \\
\text { government }\end{array}$ & $17 \%$ \\
$\begin{array}{l}\text { To obtain easy loans } \\
\text { For social welfare facilities provided by TSHDS }\end{array}$ & $88 \%$ \\
For reliable inputs such as agro-chemicals & $63 \%$ \\
$\begin{array}{l}\text { For sharing equipment such as sprayers and land preparation } \\
\text { tools }\end{array}$ & $6 \%$ \\
For obtaining reliable tea plants from the nurseries & $15 \%$ \\
\hline
\end{tabular}

\footnotetext{
*events are mutually non-exclusive
} 
TSHDS associations and giving tea small holders a voice with which to educate other tea small holders and to demand services.

Rouse found in 1996 that being part of a group contributed to knowledge, empowerment, confidence and ability to make decisions among members.

Place et al. 2002 also reported that farmer groups are valuable as a form of collective action to farmers, providing resources such as credit, labor and information. Groups allow farmers to obtain new technologies, benefit from economies of scale, enter into stable relationships with suppliers, and set rules for natural resource management.

These TSHDS can play a big role in developing their community in the tea small holdings sector. Arbab and Prager, 1991 also noted that farmer groups have played an important role both in the community and extension. These farmer groups are presently taking on an even larger role for their livelihood development. It is known that farmers transfer knowledge and technologies to each other.

The study concludes that the TSHDS has still not become an attractive organization to link the small holders in order to develop the sector through collective efforts as only about the half of the small holders are non-members of TSHDS. Also, the members of the TSHDS do not show a remarkable improvement in productivity compared to non-members to attract non-members to the organization. There is no relationship between the active membership of TSHDS and demographic characteristics of the small holders such as age, education level, income, gender and holding size. In addition to advisory service and the implementation of subsidy schemes which are the conventional roles played by the THSDA and other government authorities, other emerging issues, selling of the product, fertilizer and other inputs and welfare facilities of the tea small holders have not been sufficiently addressed by the TSHDS to attract the non-members.

\section{CONCLUSION}

The study revealed that only about $50 \%$ of the tea small holders have obtained the membership of TSHDS and $70 \%$ of tea small holders are well aware about the TSHDS.

Majority of the non-members are not interested in obtaining memberships of tea societies.

However, $75 \%$ of the society members and $85 \%$ of the non members believed that the TSHDS can do better service for their members.

About $88 \%$ of the tea society members have developed their contacts with societies to get the advisory services from the extension officers of the TSHDA and other organizations and $63 \%$ of the members like to continue the membership to get the tea subsidy to cultivate their tea small holdings and to get other benefits given by the government in time to time.

However, these tea societies paid little attention to provide some important services such as fertilizer distribution, provision of welfare facilities, provision of equipments etc to their members.

The study concludes that the TSHDS has still not become an attractive organization to link the small holders in order to develop the sector through collective efforts as only about the half of the small holders are non-members of TSHDS. Also, the members of the TSHDS do not show a remarkable improvement in productivity compared to non-members in order to attract non-members to the organization.

Therefore these TSHDS should be performed very attractive and efficient manner to provide better service to their society members. 
The study revealed a need to strengthen TSHDS through continuous training and giving other necessary assistances to enable them to provide advisory and extension services, tea cultivation subsidy and other necessary services more efficiently and effectively to their members with the assistance of the TSHDA to improve the productivity of the tea small holdings.

The study also recommend to review the functions of the TSHDS and the society structure in order to revitalize the TSHDS which may be crucial to face the problems of low productivity, degradation of the quality and other emerging issues in the future.

\section{REFERENCES}

Arbab F and Prager M 1991 An approach to promoting tree growing in Africa: The World Neighbors experience in Northern Ghana. In B. Haverkort J, Van de Kamp and A. WatersBayer, (Eds.) 1991 Joining farmers' experiments: Experiences in participatory technology development, London, UK: Intermediate Technology Publications. 65 - 76.

Census of Tea Small Holdings in Sri Lanka 2005 Department of Census and Statistics in collaboration with Tea Small holdings Development Authority under the assistance of Tea Development Project, Asian Development Bank.

Palihakkara IR, Mohammed AJ and Inoue M 2015a Current livelihood condition of and futurity of tea farming for Marginal Small Tea Farm Holders (MSTH) of Sri Lanka: Case study from Badulla and Matara Districts, Environmental and Natural Resources Research V5 (1) 11-21. http:// dx.doi.org/10.5539/enrr.v5n1p11

Palihakkara IR, Mohammed AJ, Shivakoti GP and Inoue M 2015b. Prospect of Fuel wood plantations for marginal small tea farmers: A case study in Matara and Badulla Districts, Sri Lanka. Natural Resources, 6, 566 - 576.

Place F, Kariuki G, Wangila J, Kristjanson P, Makauki A and Ndubi J 2002 Assessing the factors underlying differences in group performance: Methodological issues and empiri- cal findings from the highlands of central Kenya. CAPRi Working Paper No. 25. CGIAR Systemwide Program on Collective Action and Property Rights.

Rouse J 1996 Empowering Zambian rural women through small farmer groups. Sustainable Development Department of the Food and Agriculture Organization of the United Nations.

Tea Sakthi Fund 2016 Annual Report, Pelawatta, Battaramulla, Sri Lanka.

Tea Small Holdings Development Authority 2014 Annual report, Pelawatta, Battaramulla, Sri Lanka. 